\title{
粘土鉱物の種類の違いに着目した岩質材料の物性に関する一考察
}

\author{
河野 勝宣* 竹原 裕太* 西村 強**
}

\section{Effect of Structure of Clay Mineral on the Physical and Mechanical Properties of Rock Materials}

by

\author{
Masanori Kohno*, Yuta TakeharA* and Tsuyoshi NishimurA**
}

\begin{abstract}
It is generally known that physical and mechanical properties of rock materials significantly change by clay mineral content. Therefore, it is considered that clay mineral content or type is one of the factors that greatly affect the rock strength. In order to clarify that effect of only clay mineral content, a series of experiments has been carried out on artificial rock by the use of gypsum specimen mixed with clay minerals. The value of P-wave velocity, uniaxial compressive strength and degree of strength reduction differ with the clay mineral content and type. Comparative tests revealed that the difference of clay mineral content or type in the clay mineral-bearing rock material specimens influences the physical and mechanical properties of rock materials. Furthermore, the results suggested that uniaxial compressive strength of clay mineral-bearing rock materials under dry condition can be evaluated on the basis of interlayer bonding force (i.e. chemical bonds type) in the clay minerals. Our results can be useful and contribution as basis data when evaluating physical and mechanical properties of clay mineral-bearing rock materials.
\end{abstract}

\section{Key words:}

Clay mineral, Uniaxial compressive strength, Gypsum specimen, Interlayer bonding force

\section{1 緒 言}

新生代に形成された堆積岩類や様々な変質作用を受け た諸岩類は，粘土鉱物を含むことが多く，これらの岩類 は，岩石自体の強度が低いだけでなく，含有粘土鉱物の 影響による岩石組織の物理的または化学的な劣化度合い が大きい，また，含有粘土鉱物は，地すべりなどの斜面 災害, 建設工事における盤ぶくれや崩壊等の要因の一つ として挙げられる. そのため，粘土鉱物を含む地盤材料 や岩質材料の物性について検討した研究は各分野におい て多くなされている.

Kahraman et al. ${ }^{1)}$ は, 膨潤性粘土鉱物であるスメクタイト を様々な割合で含有する岩石を用いて一軸圧縮試験を行 った結果，スメクタイト含有量の増加に伴い，一軸圧縮 強度が低下寸ることを報告している．河野・前田 ${ }^{2}$ は，大 規模古期地すべり地内に掘削されたボーリングコア試料 を用いて各種試験・分析を実施した結果，岩石中に含ま れるスメクタイトは, 岩石の物性を大きく変化させると ともに, 岩石の強度低下に関与し, 地すべりの発生と密 接な関係があることを報告している. 石田・堤 ${ }^{3}$ は, スメ クタイトを含む 8 種類の軟岩を用いて一軸圧縮試験を実 施した結果，スメクタイト含有量が多い試料ほど乾湿の 強度比が大きく, 劣化しやすい岩石であると報告してい る。中村ほか ${ }^{4}$ は, 乾燥状態および湿潤状態における凝灰 岩類の一軸圧縮試験および圧裂引張試験を行った結果,
粘土鉱物含有量の指標として用いた比表面積が大きくな るにしたがって，湿潤状態における凝灰岩の強度低下の 程度が大きくなることを報告している。これらの報告よ り，粘土鉱物が岩石の強度低下に何らかの影響を及ぼす ことは明らかである。

日本列島の地質は, 地質時代を通じて, マグマ活動や 地款変動, 風化作用の産物が多く, 熱水変質帯や破砕帯, 風化帯が広範囲に分布しており, 多種多様な粘土鉱物が 普遍的に存在している. 粘土鉱物はその構造や化学組成 の違いから, 粘土鉱物を含む地盤材料や岩質材料は, 粘 土鉱物の種類や含有量によって, 物性が大きく変化する ことが想像される。したがって，地盤材料や岩質材料の 物性を評価するうえで, 粘土鉱物の種類や含有量に注目 することは非常に重要である．前述のように，粘土鉱物 を含む岩質材料の物性について検討した研究例はあるも のの，粘土鉱物の種類についての研究例はほとんどない. Kohno \& Maeda $^{5}$ ) は, 熱水変質軟岩の力学特性評価を行い, 乾燥状態に対する湿潤状態の岩石の強度低下率が，含ま れる粘土鉱物の種類によって異なることを明らかにして いる。しかし，どの程度の粘土鉱物含有量で岩石の物性 が変化するのかについては不明であり，また，粘土鉱物 の種類の影響についての検討も十分になされていない.

本研究では，粘土鉱物のみの影響を評価できるように， 石膏と粘土鉱物を様々な割合で混合した人工軟岩供試体

$\dagger$ 原稿受理 平成29年8月10日 Received Aug. 10, 2017 C2018 The Society of Materials Science, Japan

* 鳥取大学大学院工学研究科 $\bar{T} 680-8552$ 鳥取市湖山町南 Graduate School of Eng., Tottori Univ., Koyama-Minami, Tottori 680-8552.

** 正会員鳥取大学大学院工学研究科 $\overline{\mathrm{T}} 680-8552$ 鳥取市湖山町南

Graduate School of Eng., Tottori Univ., Koyama-Minami, Tottori 680-8552. 
を作製し，粘土鉱物の種類・含有量の違いによって，供 試体の最も基礎的な物性值と一軸圧縮強度がどのように 変化するのかについて実験的に検討した．特に，一軸圧 縮強度の差を粘土鉱物の構造の違いに基づいて考察した。

\section{2 供試体の作製方法および実験方法}

人工軟岩供試体は，Table 1 に示すような配合で，半水 石膏粉末 $\left(\mathrm{CaSO}_{4} \cdot 0.5 \mathrm{H}_{2} \mathrm{O}\right.$, 吉野石膏 (株) 製 ハイストーン $\mathrm{N}$ 型)，石英粉末 $\left(\mathrm{SiO}_{2}\right.$ ，土粒子密度 $\left.\rho_{\mathrm{s}}=2.662 \mathrm{~g} / \mathrm{cm}^{3}\right)$ お よび粘土鉱物粉末を混合し，これらの粉末に対して 5 割 の蒸留水を加えてスラリー状にした後，塩化ビニル樹脂 製の型枠に流し込み，固化（二水石膏 $\mathrm{CaSO}_{4} \cdot 2 \mathrm{H}_{2} \mathrm{O}+$ 石 英 $\mathrm{SiO}_{2}+$ 粘土鉱物）して作製した（Fig. 1). 石英粉末と 粘土鉱物粉末の割合（質量比）を種々変化させることに より，固化材である石膏の割合を一定にし，かつ，粘土 鉱物含有量の異なる供試体を作製した。粘土鉱物混合率 C は $0 \%, 10 \%, 20 \%, 30 \%$ とした．なお，供試体は，直径 $30 \mathrm{~mm}$ ，高さ $60 \mathrm{~mm}$ の円柱形とした（Fig. 1).

ここで，代表的な層状珪酸塩鉱物（粘土鉱物）の構造 模式図を Fig. 2 に示す。粘土鉱物の大部分は, Si-O など 四面体シートと $\mathrm{Al}-\mathrm{O}$ などの八面体シートの組合せからな る層状の結晶構造をもつた層状珪酸塩鉱物からなる。こ れらの 2 つのシートの組合せ（1:1 層または $2: 1$ 層）が連 続して積み重なることにより, 粘土鉱物は主に $1: 1$ 型構造 または 1:2 型構造に分類される.さらに, 陽イオン同型置 換によって生じる組成等の違いによって細かく分類され る. 本研究で用いた粘土鉱物は, Fig. 2 に示す各構造を網 羅できるように，カオリナイト（カオリン鉱物の一種, $\left.\rho_{\mathrm{s}}=2.577 \mathrm{~g} / \mathrm{cm}^{3}\right)$, 蛇紋石 $\left(\rho_{\mathrm{s}}=2.518 \mathrm{~g} / \mathrm{cm}^{3}\right), 1.0 \mathrm{~nm}$ 八ロ イサイト $\left(\rho_{\mathrm{s}}=2.736 \mathrm{~g} / \mathrm{cm}^{3}\right)$, タルク $\left(\rho_{\mathrm{s}}=2.786 \mathrm{~g} / \mathrm{cm}^{3}\right)$, 雲母粘土鉱物 $\left(\rho_{\mathrm{s}}=2.904 \mathrm{~g} / \mathrm{cm}^{3}\right)$, 緑泥石 $\left(\rho_{\mathrm{s}}=2.841 \mathrm{~g} / \mathrm{cm}^{3}\right)$ およびスメクタイト $\left(\rho_{\mathrm{s}}=2.549 \mathrm{~g} / \mathrm{cm}^{3}\right)$ の計 7 種類である. また, 岩石中によく含まれる鉱物（非粘土鉱物）として 長石 $\left(\rho_{\mathrm{s}}=2.613 \mathrm{~g} / \mathrm{cm}^{3}\right)$ および方解石 $\left(\rho_{\mathrm{s}}=2.713 \mathrm{~g} / \mathrm{cm}^{3}\right)$ についても検討した．混合粉末試料はいずれも $75 \mu \mathrm{m}$ ふ るいを通過した試料であり，これらの粉末試料は，（株） リガク製 Ultima IV を用いて不定方位 X線回折パターンに より同定した（Fig. 3)。なお，石膏一粘土鉱物混合供試体 について，X 線回折パターンおよび 2 次電子画像を確認 したところ，粘土鉱物（または非粘土鉱物）と石膏の混 合による新たな反応生成物は見られていない.

一軸圧縮試験は, (株) 誠研舎製の圧縮試験機 DTC-127B を用いて行った。圧縮荷重の測定および記録には，（株） 東京測器研究所製の圧縮荷重計 CLP-20B および超小型動 ひずみレコーダ DC-204R を用いた。試験時の軸ひずみ速 度は $0.1 \% / \mathrm{min}$ とした。供試体の含水状態による強度の違 いを把握するため, 一軸圧縮試験は, 乾燥状態（供試体 を $70^{\circ} \mathrm{C}$ で 24 時間乾燥させた状態）および飽和状態（デ シケータ内で供試体を浸水させ, 24 時間真空脱気した後, 大気圧下において 24 時間浸水させた状態）の供試体につ いて行い, 1 種の供試体につき 4 本以上の計 268 本につい
Table 1 Mix proportion of gypsum specimens.

\begin{tabular}{l|lcc}
\hline Clay mineral content & Bassanite & Quartz & Clay mineral \\
\hline$C_{\mathrm{c}}=0 \%$ & $70 \%$ & $30 \%$ & $0 \%$ \\
$C_{\mathrm{c}}=10 \%$ & $70 \%$ & $20 \%$ & $10 \%$ \\
$C_{\mathrm{c}}=20 \%$ & $70 \%$ & $10 \%$ & $20 \%$ \\
$C_{\mathrm{c}}=30 \%$ & $70 \%$ & $0 \%$ & $30 \%$ \\
\hline
\end{tabular}

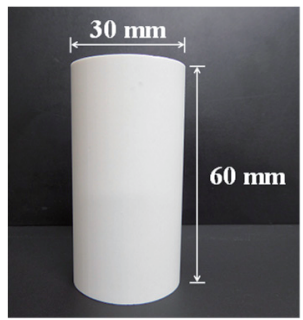

Fig. 1 Gypsum specimen.

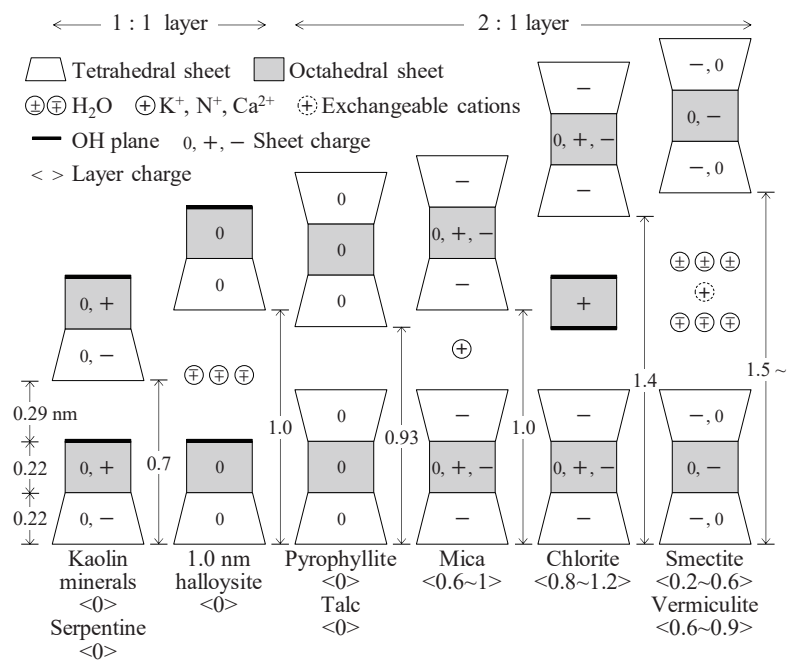

Fig. 2 Schematic crystal structure of layer silicate (based on Shirozu ${ }^{6)}$ ).

て行った。また, 乾燥密度, 飽和密度, 有効間隙率, 吸 水率および $\mathrm{P}$ 波速度を求めた。 なお，本研究では，石膏 の水和水を脱水させないために, 一軸圧縮試験および物 理試験における供試体乾燥時の温度を $70^{\circ} \mathrm{C}$ とし。

\section{3 実験結果および考察}

\section{$3 \cdot 1$ 石膏一粘土混合供試体の基本物性}

石膏一粘土鉱物混合供試体の乾燥密度, 飽和密度, 有 効間隙率, 吸水率および $\mathrm{P}$ 波速度を Fig. 4 に示す. 粘土鉱 物混合率 $C_{\mathrm{c}}=0 \%$ の石膏供試体の乾燥密度は $1.20 \mathrm{~g} / \mathrm{cm}^{3}$, 飽和密度は $1.65 \mathrm{~g} / \mathrm{cm}^{3}$, 有効間隙率は $45.0 \%$, 吸水率は $37.5 \%$ であ, 乾燥状態および飽和状態における $\mathrm{P}$ 波速度 はそれぞれ $2.48 \mathrm{~km} / \mathrm{s}$ および $2.25 \mathrm{~km} / \mathrm{s}$ である.これらの值 は, 泥岩や凝灰岩などの軟岩の物性值の範疇にある。

石膏一粘土鉱物混合供試体の乾燥密度および飽和密度 のいずれも粘土鉱物（または非粘土鉱物）混合率 $C_{\mathrm{c}}$ の違 いによる大きな差はみられず, また, 石膏供試体 $\left(C_{\mathrm{c}}=0 \%\right)$ の密度のおよそ $0.1 \mathrm{~g} / \mathrm{cm}^{3}$ の範囲にある（Fig. 4A）。有効 

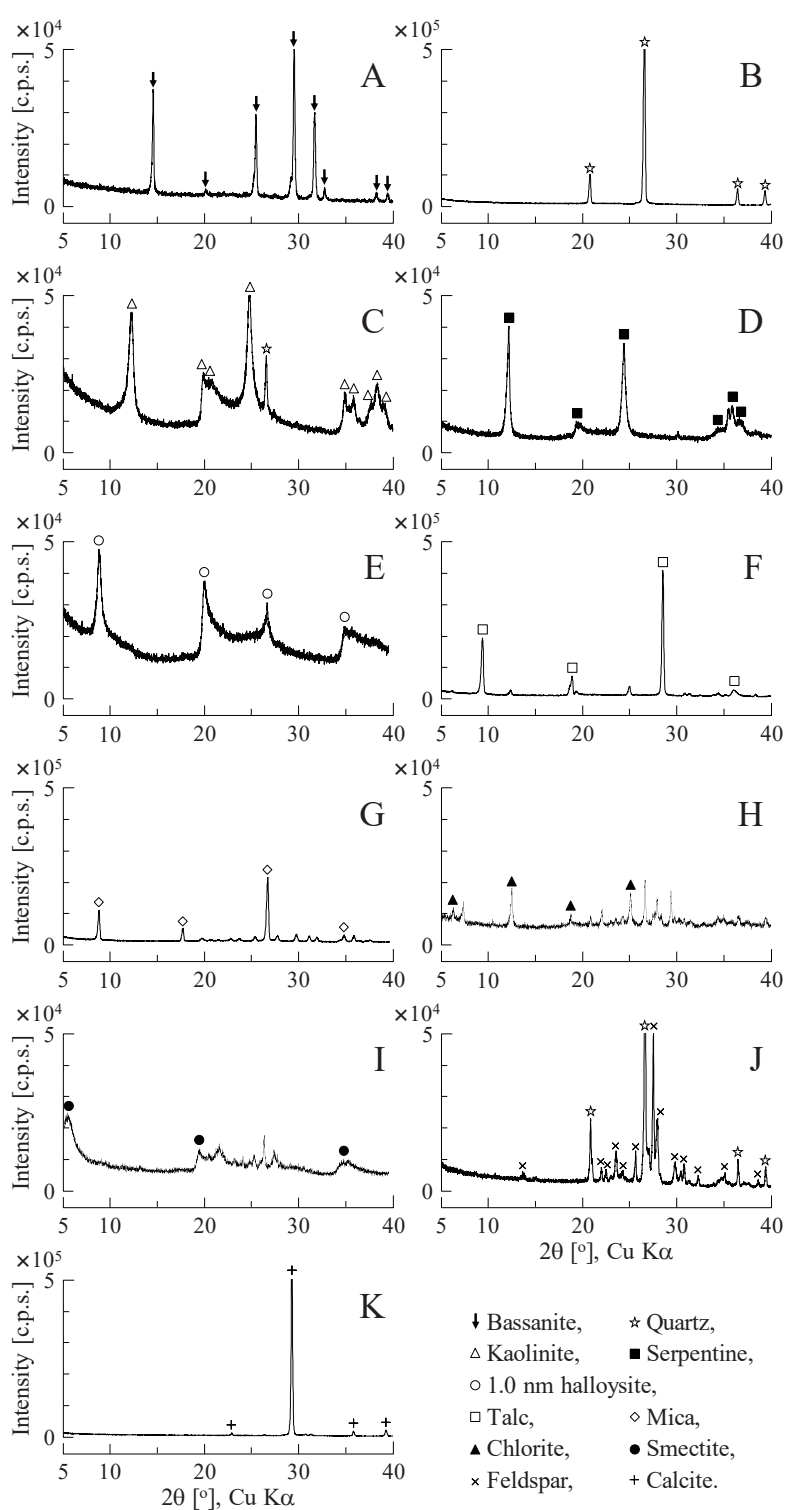

K

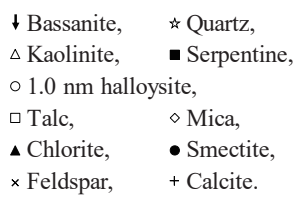

Fig. 3 Unoriented X-ray powder diffraction (XRD) patterns of bassanite (A), quartz (B), kaolinite (C), serpentine (D), $1.0 \mathrm{~nm}$ halloysite $(\mathrm{E})$, talc $(\mathrm{F})$, mica $(\mathrm{G})$, chlorite $(\mathrm{H})$, smectite $(\mathrm{I})$, feldspar $(\mathrm{J})$ and calcite $(\mathrm{K})$ powders.

間隙率も $C_{\mathrm{c}}$ の違いによる大きな差はみられず，40～50\% の範囲にある (Fig. 4B)，吸水率は，30４5\%の範囲にあ り, 混合する粘土鉱物の種類により，違いはみられるが， 同種の供試体に着目すると， $C_{\mathrm{c}}$ の違いによる大きな差は みられない (Fig. 4C)。乾燥状態および飽和状態における 供試体のP 波速度は，それぞれ，2.2〜 $2.7 \mathrm{~km} / \mathrm{s}$ および 1.6 $\sim 2.5 \mathrm{~km} / \mathrm{s}$ の範囲にある. また, $\mathrm{P}$ 波速度は, 飽和状態よ りも乾燥状態における供試体のほうが大きく, 乾燥状態 における石膏一雲母粘土鉱物混合供試体と，飽和状態に おける石膏一蛇紋石混合供試体および石膏一緑泥石混合 供試体を除くと，いずれも， $C_{\mathrm{c}}$ の増加に伴い，低下する 傾向が見られる (Fig. 4D)。ただし，石膏一非粘土鉱物混 合供試体では， $C_{\mathrm{c}}$ の違いによる大きな差は見られない。

\section{$3 \cdot 2$ 応カーひずみ曲線と接線弾性係数}

乾燥状態および飽和状態における石膏一粘土鉱物混合
供試体の一軸圧縮試験時の応力ーひずみ線図を Fig. 5A に 示寸. 同図には, 石膏供試体 $\left(C_{\mathrm{c}}=0 \%\right)$, 石膏一スメクタ イト混合供試体 $\left(C_{\mathrm{c}}=30 \%\right)$ および石膏一長石混合供試体 $\left(C_{\mathrm{c}}=30 \%\right)$ の代表的な試験結果のみを示している.

乾燥状態における石亳供試体 $\left(C_{\mathrm{c}}=0 \%\right)$ および石膏一 長石混合供試体 $\left(C_{\mathrm{c}}=30 \%\right)$ の応力一ひずみ曲線は, 軸ひ ずみの増加に伴い, 弾性挙動を示したまま脆性破壊に至 る傾向を示寸。一方, 乾燥状態における石膏一スメクタ イト混合供試体と飽和状態におけるいずれの供試体も, 最大応力に達した後, 破壊に至るまでにひずみの増加が 認められる．乾燥状態における一軸圧縮強度の $50 \%$ にお ける接線弾性係数を求めると, 石膏供試体 $\left(C_{\mathrm{c}}=0 \%\right)$ お よび石膏一長石混合供試体 $\left(C_{\mathrm{c}}=30 \%\right)$ の接線弾性係数は, 乾燥状態では $3.8 \mathrm{GPa}$ 前後, 飽和状態では $1.4 \mathrm{GPa}$ 前後で あり，いずれの含水状態においても長石混合の有無によ る差は見られない。一方, スメクタイト混合供試体の接 線弾性係数は, 乾燥状態では $2.8 \mathrm{GPa}$ 程度, 飽和状態では $0.1 \mathrm{GPa}$ 程度であり, スメクタイトの混合により, 接線弾 性係数が低下寸ることがわかる，特に，飽和状態におけ る石膏一スメクタイト混合供試体の接線弾性係数は, 乾 燥状態に比べて大きく低下することがわかる，いずれの 供試体においても，一軸圧縮試験によって得られる応力 一ひずみ曲線の傾向と接線弾性係数の值は軟岩と同様で ある。

乾燥状態および飽和状態における石膏一粘土鉱物混合 供試体の $C_{\mathrm{c}}$ と接線弾性係数との関係を Fig. $5 \mathrm{~B}$ に示す. 乾 燥状態における接線弾性係数は, 石膏一緑泥石混合供試 体 $\left(C_{\mathrm{c}}=10 \%\right)$ の $4.4 \mathrm{GPa}$ が最も大きく, 石膏一タルク混 合供試体 $\left(C_{\mathrm{c}}=30 \%\right)$ の $2.0 \mathrm{GPa}$ が最も小さい. 一方, 飽 和状態における接線弾性係数は, 石膏一長石混合供試体 $\left(C_{\mathrm{c}}=10 \%\right)$ の $1.9 \mathrm{GPa}$ が最も大きく, 石膏一スメクタイ 卜混合供試体 $\left(C_{\mathrm{c}}=30 \%\right)$ の $0.1 \mathrm{GPa}$ が最も小さい. 飽和 状態における接線弾性係数は, 石膏一スメクタイト混合 供試体のほかに，蛇紋石および緑泥石を除く石膏一粘土 鉱物混合供試体において小さい傾向にある。乾燥状態お よび飽和状態における石膏一粘土鉱物混合供試体の接線 弾性係数は, いずれの含水状態も, 石膏供試体 $\left(C_{\mathrm{c}}=0 \%\right)$ よりも大きい值を示す供試体もあるが， $C_{\mathrm{c}}=10 \%$ ～30\%の 範囲では， $C_{\mathrm{c}}$ の増加に伴い，低下傾向がみられる．なお， 非粘土鉱物では，飽和状態における石膏一長石混合供試 体を除くと, $C_{\mathrm{c}}$ の増加に伴い, 接線弾性係数が一部増大 する傾向もみられる. 以上のことから, 岩質材料に含有 する粘土鉱物は, 弾性係数の低下を引き起こすとともに, その程度は粘土鉱物の種類によって異なることが言える。

\section{$3 \cdot 3$ 粘土鉱物混合率と一軸圧縮強度との関係}

乾燥状態および飽和状態における石膏一粘土鉱物混合 供試体の $C_{\mathrm{c}}$ と一軸圧縮強度との関係を Fig. $6 \mathrm{~A}, \mathrm{~B}$ に示す. 同図には，それぞれ，4 本以上の供試体の試験結果の平均 值をプロットしている。これらの一軸圧縮強度の変動係 数はすべて $15 \%$ 以下であり，そのうちの半数以上が $10 \%$ 以下である。 

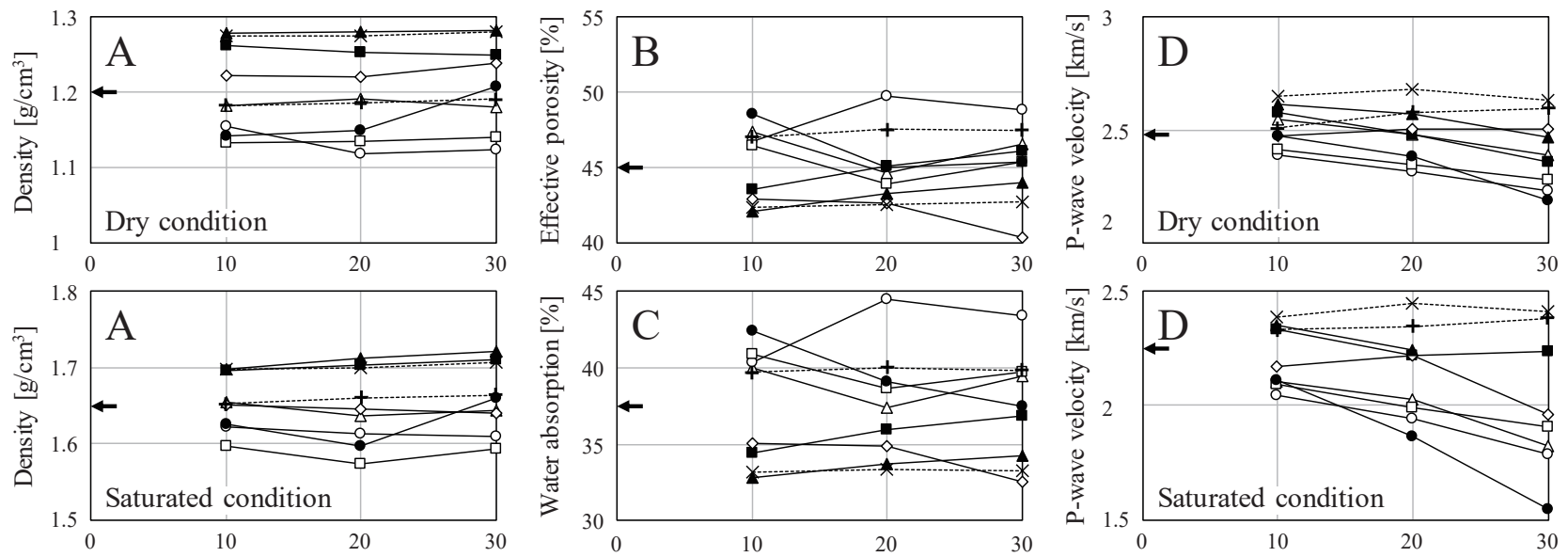

Clay or non-clay mineral content $C_{\mathrm{c}}[\%]$

Clay or non-clay mineral content $C_{\mathrm{c}}[\%]$

Clay or non-clay mineral content $C_{c}[\%]$

$\leftarrow$ Gypsum specimen $\left(C_{\mathrm{c}}=0 \%\right)$, Mixed samples ( $\triangle$ Kaolinite, $\square$ Serpentine, $01.0 \mathrm{~nm}$ halloysite, $\square$ Talc, $\diamond$ Mica,

$\Delta$ Chlorite, - Smectite, $\times$ Feldspar (dashed line), + Calcite (dashed line))

Fig. 4 Physical properties of gypsum specimen mixed with clay or non-clay mineral (A: density, B: effective porosity, C: water absorption, D: P-wave velocity).
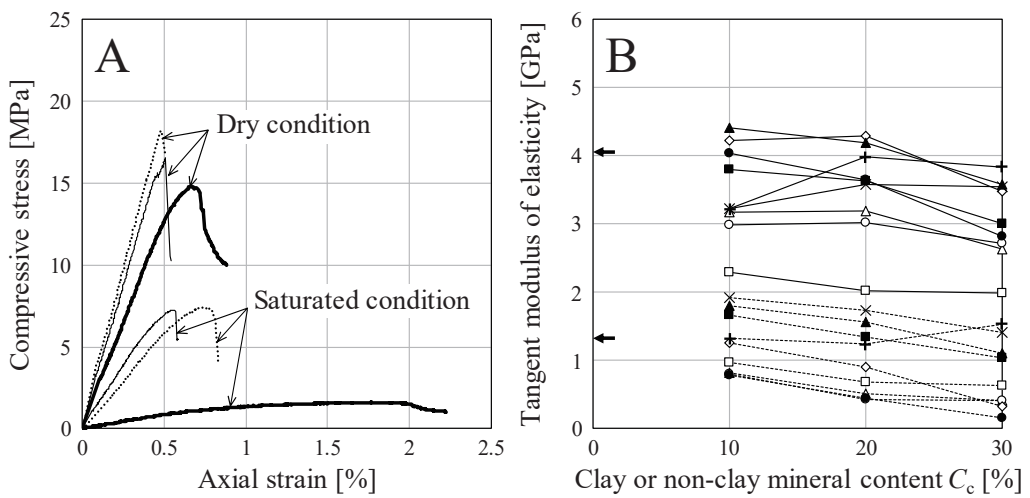

Fig. A ….. Gypsum specimen $\left(C_{\mathrm{c}}=0 \%\right)$, Mixed samples $\left(C_{\mathrm{c}}=30 \%,-\right.$ Smectite, -Feldspar $)$

Fig. B $\leftarrow$ Gypsum specimen $\left(C_{\mathrm{c}}=0 \%\right)$, Mixed samples $(\triangle$ Kaolinite, $\square$ Serpentine,

$\circ 1.0 \mathrm{~nm}$ halloysite, $\square$ Talc, $\diamond$ Mica, $\Delta$ Chlorite, $\bullet$ Smectite, $\times$ Feldspar, +Calcite)

Fig. 5 One example of stress-strain curve on the uniaxial compressive strength test of gypsum specimen mixed with smectite $30 \%$ or feldspar $30 \%$ (A) and tangent modulus of elasticity (B). Solid and dashed lines in Fig. B are dry and saturated conditions, respectively.

乾燥状態および飽和状態における石稁供試体 $\left(C_{\mathrm{c}}=0 \%\right)$ の一軸圧縮強度は，それぞれ，18.2 MPa および $7.7 \mathrm{MPa}$ であり, 飽和状態における供試体の方が小さい，石膏一 粘土鉱物混合供試体の一軸圧縮強度は，いずれの含水状 態においても $C_{\mathrm{c}}=10 \%$ ３0\%の範囲では， $C_{\mathrm{c}}$ の増加に伴 い，低下傾向がみられ，その低下の様相に大きな差は見 られない（Fig. 6A）。一方，石膏一非粘土鉱物混合供試体 の一軸圧縮強度は, $C_{\mathrm{c}}$ の増加に伴い, 乾燥状態では増加 傾向を示し，飽和状態では大きな違いは見られず，石膏 一粘土鉱物混合供試体の試験結果とは異なる傾向がみら れた（Fig. 6B）。このことからも，粘土鉱物の含有が岩質 材料の強度低下に関係寸ることは明らかである。乾燥状 態および飽和状態における一軸圧縮強度は，いずれの含 水状態においても石膏一緑泥石混合供試体 $\left(C_{\mathrm{c}}=10 \%\right)$ が

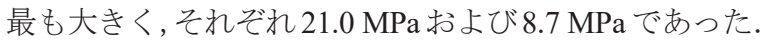
一方, 乾燥状態および飽和状態の一軸圧縮強度の最小値
は, いずれも $C_{\mathrm{c}}=30 \%$ において見られ，それぞれ，石高 一タルク混合供試体の $8.8 \mathrm{MPa}$ および石膏一スメクタイ 卜混合供試体の $1.6 \mathrm{MPa}$ であった. これらの供試体の一軸 圧縮強度は, 石膏供試体 $\left(C_{\mathrm{c}}=0 \%\right)$ に比べて, 乾燥状態 ではおよそ $50 \%$ 低下しており，飽和状態ではおよそ $80 \%$ も低下寸ることがわかった． $C_{\mathrm{c}}=10 \%$ 30\%の範囲におけ る石膏一粘土鉱物混合供試体における一軸圧縮強度の最 大值と最小值の差は, いずれの $C_{\mathrm{c}}$ においても, 乾燥状態 では $9 \mathrm{MPa}$ 程度, 湿潤状態では $5 \mathrm{MPa}$ 程度であり, 粘土 鉱物の種類の違いによって, 一軸圧縮強度に差があるこ とがわかる.ゆえに, 含有する粘土鉱物の種類は岩質材 料の強度低下に影響を及ぼす要因の一つであり, 今後, 粘土鉱物を含む地盤材料の力学特性評価をする際には, 粘土鉱物の種類についても注意する必要があると言える. なお，乾燥状態における $C_{\mathrm{c}}=10 \%, 20 \%$ において，一部 の供試体の一軸圧縮強度が石亳供試体 $\left(C_{\mathrm{c}}=0 \%\right)$ の一軸 


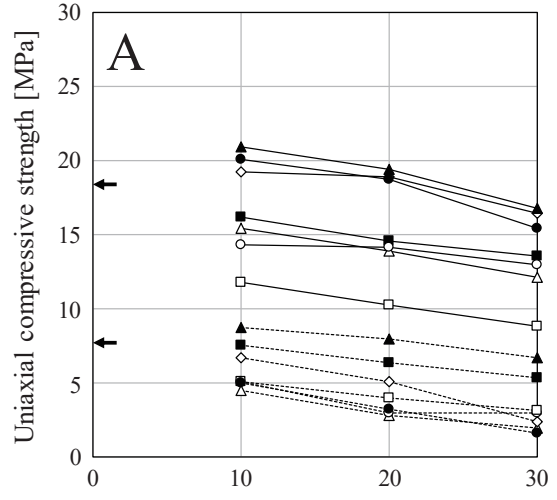

Clay mineral content $C_{\mathrm{c}}[\%]$

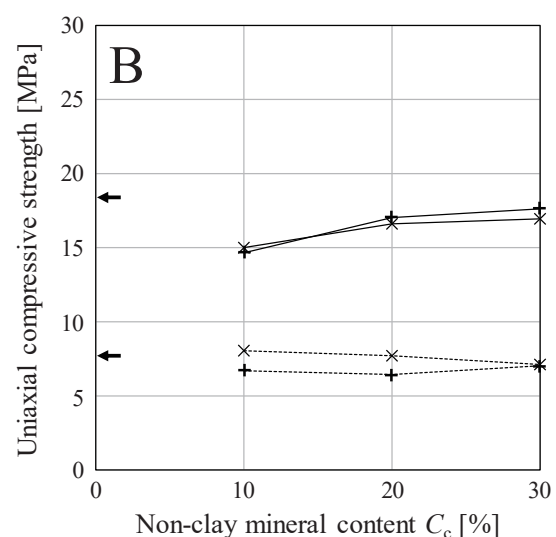

Non-clay mineral content $C_{\mathrm{c}}[\%]$

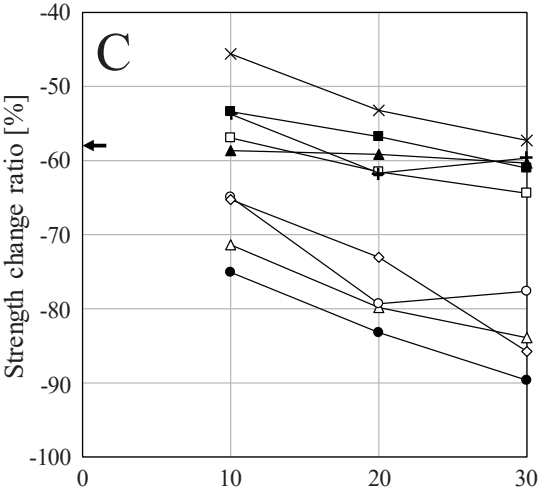

Clay or non-clay mineral content $C_{\mathrm{c}}[\%]$

$\leftarrow$ Gypsum specimen $\left(C_{\mathrm{c}}=0 \%\right)$, Mixed samples $(\triangle$ Kaolinite, $\square$ Serpentine, $\bigcirc 1.0 \mathrm{~nm}$ halloysite, $\square$ Talc, $\diamond$ Mica,

$\Delta$ Chlorite, $\bullet$ Smectite, $\times$ Feldspar, + Calcite)

Fig. 6 Relationships between clay or non-clay mineral content and uniaxial compressive strength (A, B), and strength change ratio (C) of test of gypsum specimen mixed with clay or non-clay mineral. Solid and dashed lines in Figs. A and B are dry and saturated conditions, respectively.

圧縮強度よりも大きく，これについては，五味・岡本 7) の実験においても同様の傾向を示している。このことに ついては，後述する粘土鉱物の層間の結合力が関係して いると考えられるが, 詳細については今後の課題である.

\section{$3 \cdot 4$ 粘土鉱物の層間結合力と一軸圧縮強度との関係}

乾燥状態における石膏一粘土鉱物混合供試体の一軸圧 縮強度（Fig. 6A）に注目すると, 強度分布の特徴として, ある特定の強度值に分布し，それらは大きく 3 つに分布 しているようである.すなわち, $C_{\mathrm{c}}=10 \%$ を例に挙げると， 緑泥石，雲母粘土鉱物およびスメクタイトは，一軸圧縮 強度が $20 \mathrm{MPa}$ 程度，カオリナイト，蛇紋石および $1.0 \mathrm{~nm}$ ハロイサイトは一軸圧縮強度が $15 \mathrm{MPa}$ 程度，タルクは一 軸圧縮強度が $12 \mathrm{MPa}$ 程度の強度值に特徵的に分布する. 便宜上，強度值ごとに Group I ～III の 3 つの分類する. Group I は緑泥石, 雲母粘土鉱物およびスメクタイト, Group II はカオリナイト, 蛇紋石および $1.0 \mathrm{~nm}$ ハロイサ イト, Group III はタルクである。粘土鉱物混合率が変化 してもこれらの Group 内の粘土鉱物の組合せに変化はな い. 各 Group 内の粘土鉱物の特徴について Fig. 2 に基づい て記述するとともに，一軸圧縮強度との関係について考 察する. Group I における粘土鉱物は，単位層同士が主と してイオン結合により結びついており，層間には陽イオ ンまたは水酸化物シートを持つ $2: 1$ 型構造の粘土鉱物で ある（Fig. 2)，層間に働く力（結合力）は Fig. 2 に示すよ うに，層電荷によって表すことができる。この層電荷の 大きさは鉱物の物性に大きく関連する 6)といわれている. Group I における粘土鉱物では, 緑泥石, 雲母粘土鉱物, スメクタイトの順に層電荷が大きいが，これらの粘土鉱 物を含む供試体の一軸圧縮強度に大きな差はないことか ら，層電荷の大きさは一軸圧縮強度には大きな影響を与 えるものではないようである。ただし，これらの試験結 果は 1 回の乾燥によって得られたものであり, スメクタ イトのように湿潤時に層間に水を取り込んで膨潤，乾燥 時に脱水によって収縮し，材料自体を劣化させるような

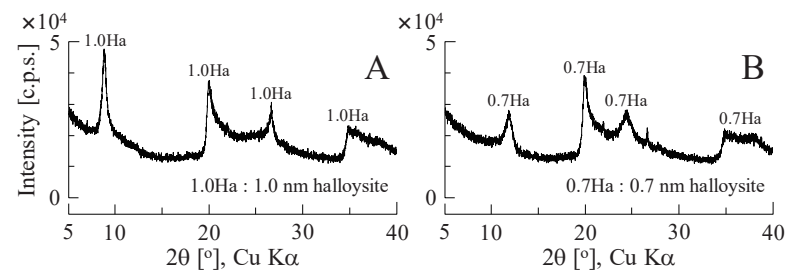

Fig. 7 XRD patterns of $1.0 \mathrm{~nm}$ halloysite (A, identical to Fig. 3E) and $0.7 \mathrm{~nm}$ halloysite (B).

粘土鉱物は, おそらく, 乾湿繰り返し後に試験を実施す ると, 同じ乾燥状態でも緑泥石や雲母粘土鉱物混合供試 体に比べて強度は小さくなると考えられる. Group II にお ける粘土鉱物は, 層電荷が 0 であり, 水素結合によって 形成される 1:1 型構造の粘土鉱物である（Fig. 2)。このう ち, $1.0 \mathrm{~nm}$ ハロイサイトの層間には 1 枚の水分子層が挟 まれ，層間に働く結合力は弱い $)^{6}$. 層間の水分子は $70^{\circ} \mathrm{C}$ で容易に脱水し, 底面間隔も $1.0 \mathrm{~nm}$ から $0.7 \mathrm{~nm}$ になる (Fig. 7). それゆえ, $1.0 \mathrm{~nm}$ ハロイサイト混合供試体の一軸圧 縮強度とカオリナイトや蛇紋石混合供試体との間に大き な差が見られなかったと考えられる. Group III における 粘土鉱物は，層電荷が 0 であり，ファンデルワールスカ によって形成される 2:1 型構造の粘土鉱物である (Fig. 2).

以上のように，層間に働く化学結合の種類の違いによ って，乾燥状態における一軸圧縮強度に差が見られた。 一般に，層間に働く結合力は，イオン結合，水素結合， ファンデルワールスカの順に大きい. 本実験で得られた 一軸圧縮強度の違いも, これらの結合力の大きさを反映 している. すなわち, Group I (主にイオン結合), Group II (水素結合), Group III（ファンデルワールスカ）の順に一 軸圧縮強度は大きい結果となった。 パイロフィライトお よびバーミキュライトについては, 本研究で検討してい ないが，同様の実験を行った場合，それぞれ，Group III および Group I と同様の強度を示すと考えられる。

なお，飽和状態については，乾燥状態と同様の傾向は 
見られなかった。これは，含水による層間の結合力の低 下に加えて，粘土鉱物は他の鉱物に比べて比表面積が大 きいことや，陽イオン交換時の水和エネルギー，さらに， 間隙水圧等の影響が複雑に関係するため, 乾燥状態と同 様な傾向が見られなかったと考えられる.

\section{$3 \cdot 5$ 粘土鉱物混合率と強度変化率との関係}

Fig. 6A, B に示されるように, 供試体の含水状態により, 一軸圧縮強度に差が見られた。 そこで，飽和状態におけ る一軸圧縮強度が乾燥状態の強度よりどれだけ变化して いるかを示すため, 強度変化率 SCR を式(1)によって算出 した.

$$
S C R=\frac{S_{\text {csat }}-S_{\text {cdry }}}{S_{\text {cdry }}} \times 100(\%)
$$

ここで，添え字の dry および sat は乾燥状態および飽和状 態における供試体の一軸圧縮強度 $S_{\mathrm{c}}$ を表す. SCR が負の 場合は, 乾燥状態に比べて飽和状態における供試体の一 軸圧縮強度 $S_{\mathrm{c}}$ が低下していることを意味する。

$C_{\mathrm{c}}$ と $S C R$ との関係を Fig. $6 \mathrm{C}$ に示す. 石膏供試体 $\left(C_{\mathrm{c}}=\right.$ $0 \%)$ の SCR は-57.5\%であり，石膏一長石混合供試体（ $C_{\mathrm{c}}$ $=10 \%$ ）の-45.6\%が最も小さく, 石膏一スメクタイト混合 供試体 $\left(C_{\mathrm{c}}=30 \%\right)$ の- $89.7 \%$ が最も大きい. $C_{\mathrm{c}}$ の増加に 伴い, $S C R$ が負の方向に大きくなる傾向が見られ，粘土 鉱物の種類によって, SCR の值は異なる．特に，非粘土 鉱物である長石および方解石，蛇紋石や緑泥石混合供試 体では, $S C R$ が石膏供試体 $\left(C_{\mathrm{c}}=0 \%\right)$ と同程度であるか, または, $C_{\mathrm{c}}$ の増加による $S C R$ に大きな変化は見られない. 一方, カオリナイト, $1.0 \mathrm{~nm}$ ハロイサイト, 雲母粘土鉱 物，スメクタイト混合供試体では SCR が他の粘土鉱物混 合供試体よりも大きい. これら粘土鉱物の種類による $S C R$ の違いは, Kohno \& Maeda ${ }^{5)}$ の結果と整合的であり, カ才 リナイト, $1.0 \mathrm{~nm}$ ハロイサイト, 雲母粘土鉱物, スメク タイト等を含有する岩質材料は, 強度低下に及ぼす含水 の影響が他の粘土鉱物に比べて大きいことがわかる。こ れは，粘土鉱物の比表面積の大きさが異なることや，層 間への水の浸透量も少なからず影響しているものと推察 されるが，前述のように，飽和状態での一軸圧縮強度に おいては，粘土鉱物の性質に加え，間隙水圧等の影響も 含まれており，これについては，今後，総合的に検討し， 詳細を明らかにする必要がある.

\section{4 結 言}

本研究では，石膏と粘土鉱物を様々な割合で混合した 人工軟岩供試体を作製し, 粘土鉱物の種類・含有量の違 いによって, 物性值と一軸圧縮強度がどのように変化す るのかについて検討した。 その結果，石膏一粘土鉱物混 合供試体の $\mathrm{P}$ 波速度，一軸圧縮強度および乾湿による強 度変化率は，含有する粘土鉱物の種類・含有量によって 異なることがわかった。特に, 乾燥状態における石膏一 粘土鉱物混合供試体の一軸圧縮強度は, 最大值と最小值 で $9 \mathrm{MPa}$ 程度の差がみられ, 粘土鉱物の種類の違いによ
って, 一軸圧縮強度に大きな差がみられた. 本研究では, この一軸圧縮強度の差を粘土鉱物の構造の違いに基づい て考察した. 飽和状態における一軸圧縮強度に与える粘 土釷物の種類や含有量の影響については課題を残すが, 乾燥状態における一軸圧縮強度は, 含有粘土鉱物が緑泥 石，雲母粘土鉱物およびスメクタイト (イオン結合), カ オリナイト, 蛇紋石および $1.0 \mathrm{~nm}$ 八ロイサイト（水素結 合), タルク（ファンデルワールスカ）の順に大きい結果 となった。これは, 含有粘土鉱物の層間に働く化学結合 の種類, 寸なわち, 結合力の大小関係を反映するような 結果であった。

以上の結果は, 含有粘土鉱物の種類は岩質材料の強度 低下に影響を及ぼす要因の一つであり, 今後, 粘土鉱物 を含む地盤材料や岩質材料の力学特性評価をする上で, 貴重な知見になると考えられる.

本研究の一部は, 日本学術振興会科学研究費 (課題番 号：16K21174）の助成を受けて実施したものである。ま た, 実験には, 鳥取大学工学部土木工学科卒業生重松祐 汰君の協力を得た．記して，謝意を表する.

\section{参 考 文 献}

1) S. Kahraman, A. S. Aloglu, B. Aydin and E. Saygin, "The effect of clay content on the strength of clay-bearing rocks", Proceedings of 9th Asian Rock Mechanics Symposium, RMC4-P174 (2016).

2) M. Kohno and H. Maeda, "Relationship between cylinder (longitudinal) point load strength and uniaxial compression strength for smectite-bearing fine tuffs in a soft and semi-hard rock boundary area: Example of the Upper Miocene Ikutawara Formation from the Ikutahara-Minami landslide area", Landslides - Journal of the Japan Landslide Society, Vol.47, No.1, pp.17-25 (2010).

3) R. Ishida and S. Tsutsumi, "Physical properties of smectite bearing soft rocks (Part 2) -Texture and swelling pressure-", Journal of the Clay Science Society of Japan, Vol.34, No.1, pp.22-34 (1994).

4) D. Nakamura, T. Goto, Y. Ito, S. Yamashita, T. Kawaguchi and S. Kataoka, "Study on the differences in strength of rocks under dry and wet conditions", Technical Report of the 52nd Annual Meeting of the Hokkaido Branch, Japanese Geotechnical Society, No.52, pp.157-164 (2012).

5) M. Kohno and H. Maeda, "Relationship between point load strength index and uniaxial compressive strength of hydrothermally altered rocks", International Journal of Rock Mechanics and Mining Sciences, Vol.50, pp.147-157 (2012).

6) H. Shirozu, "Clay Mineralogy: The basis of clay science (New edition)", pp.1-185 (2012) Asakura Publishing.

7) S. Gomi, and M. Okamoto, "Strength of artificial soft rocks using clays", Soil Mechanics and Foundation Engineering, Vol.44, No.5, pp.21-23 (1996). 